\title{
Research on the Impact of Supply Chain Integration of Startups: Service Supply Chain Perspective
}

\author{
Han Lin, Qian Lin \\ School of Business and Administration, South China University of Technology, Guangzhou, China \\ Email: 469964226@qq.com
}

How to cite this paper: Lin, H. and Lin, Q. (2018) Research on the Impact of Supply Chain Integration of Startups: Service Supply Chain Perspective. Open Journal of Social Sciences, 6, 255-274. https://doi.org/10.4236/jss.2018.64022

Received: April 4, 2018

Accepted: April 27, 2018

Published: April 30, 2018

Copyright $\odot 2018$ by authors and Scientific Research Publishing Inc. This work is licensed under the Creative Commons Attribution International License (CC BY 4.0).

http://creativecommons.org/licenses/by/4.0/

\section{(c) (i) Open Access}

\begin{abstract}
As the potential power of social economic development, the importance of startups has attracted more and more attention from academia. The service supply chain, led by the service integrator, can help the startups to improve the performance of the enterprise, achieve better supply chain integration, and go through their "infancy" period successfully. However, the research about the factors that influence the integration of service supply chain and how these factors affect the supply chain integration of startups remains to be explored. Based on the practical problems and theoretical research status above, this study constructs a theoretical hypothesis model of the relationship between interaction, supply chain finance and supply chain integration, and we take the survey data of 65 startups in Pearl River Delta of China as samples and use hierarchical regression analysis to carry out hypothesis testing. The result shows that, from the perspective of startups, interaction has a positive impact on supplier integration, internal integration and customer integration, and supply chain finance has a positive impact on internal integration. The main significance of this study is to make up for the vacancy on this part of the academic community in the service supply chain, and help provide some reference basis for start-up enterprises' supply chain integration.
\end{abstract}

\section{Keywords}

Supply Chain Services, Startups, Supply Chain Integration, Interaction, Supply Chain Finance

\section{Introduction}

With the transformation and upgrading of the world economic structure, the old mode of production is now seeking new breakthroughs. For the traditional 
product manufacturing supply chain, its marginal benefit shows a decreasing trend, and the feature of replicability also increases the operational risk of manufacturing enterprises. Therefore, more and more manufacturing enterprises are gradually transforming from "product-centric" to "service-oriented", which means that the focus will be extended from manufacturing sector to the entire product life cycle. As a result, service outsourcing has become an important strategy for service-oriented enterprises to pursue industrial upgrading, which also promotes the traditional product manufacturing supply chain gradually transformed into a service supply chain.

Supported by the development of internet technology and internet economy, the global wave of entrepreneurship is rising, and that is especially remarkable in China under the vigorous promotion and support of Chinese government. However, most of the startups are faced with many problems, where limited funds and poor social relations are the most troublesome ones. Many startups spend a lot of effort on non-core aspects such as obtaining liquidity, seeking partners and building social relations, which distract their concentration on the core business and hinder the development of enterprises. As a result, according to statistics in [1], China now has an average of 150,000 private-owned enterprises newly added each year, but at the same time more than 100,000 private-owned enterprises go bankrupt. Besides, about $60 \%$ of the private-owned enterprises cannot hold up for five years and the average life expectancy of them are only 2.9 years. Aimed at solving the problems above, supply chain service enterprises emerge as the times require and open up a new market. The supply chain service enterprises integrate various resources and build up a platform, where service request of startups (customers) are decomposed and outsourced to appropriate service providers (suppliers) on the platform. In that progress, the supply chain service enterprises are responsible for customer demand decomposition, service factor matching, information transfer, partnership maintenance and so on. Thanks to that, startups can focus on their core business.

Startups are not only a new power to stimulate national economic growth, but also an important force to stimulate domestic demand and create jobs. Therefore, how to help startups grow better is an issue of particular concern to all sectors of society. Considering the difficulties encountered in the early development of startups, this paper discusses the impact of supply chain finance and interaction on the supply chain integration of startups from the perspective of service supply chain. The main significance of this study is to make up for the vacancy on this part of the academic community in the service supply chain, and help provide some reference basis for start-up enterprises' supply chain integration.

\section{Theoretical background}

\subsection{Supply Chain Integration}

Increasing the level of supply chain integration among supply chain members has become a necessity for the improving of the performance of the supply chain 
system. Despite the abundant research on unidimensional supply chain relationships, the SCI construct is a relatively new as an area of research [2]. Supply chain integration is defined as "the degree to which a firm can strategically collaborate with its supply chain partners and collaboratively manage the intra- and inter-organization processes to achieve effective and efficient flows of product and services, information, money and decisions with the objective of providing maximum value to customers at low cost and high speed" [2]. Vickery et al. state that the challenge of supply chain integration is the managerial capacity for combining resources and competencies from various supply chain members and business units, and directing all relevant parties towards an expanded resource base and competitive advantage [3], which means that it should be strategically managed as an integrated system as opposed to individually optimized fragmented subsystems. Maloni and Benton report that in order to provide customers with greater value and gain competitive advantage, a higher level of cooperation is required for supply chain partners, which leads to integration of the supply chain [4].

Some researchers characterize integration as interaction, in which communication in form of and information flows and meetings are employed to unite firms on supply chains [5] [6] [7]. Another type of researches characterize integration as collaboration, where firms on a supply chain or departments within a firm work collectively under common objectives [8] [9]. Others put forth a composite view which characterize integration as information sharing and involvement [10] [11], while empirical work by these researches fail to delineate clearly between information sharing and involvement. This study build upon previous research on the SCI construct, arguing that the diverse dimensions of SCI being collapsed into three dimensions, supplier integration, internal integration and customer integration. In which supplier and customer integration are commonly referred to as external integration.

\subsection{Resource-Based Theory}

In 1984, Wernerfelt put forward "The Resource-Based Theory of the Firm", and it symbolized the formal generation of the resource-based theory [12]. After that, the theory has been continually supplemented and improved by Barney Peterafand many other scholars through theoretical and empirical research [13] [14]. Nowadays, the resourced-based theory can be roughly divided into three schools---traditional resource theory, enterprise competence theory and enterprise knowledge-based theory. 1) The traditional resource theory, represented by Wernerfelt's “The Resource-Based Theory of the Firm”, believes that an enterprise is a unique collection of all resources. In order to stand out in the competition, enterprises must acquire the valuable, scarce, heterogeneous, inimitable and irreplaceable resources. The focus of supply chain integration is to integrate the decisive resources with the features above, especially the internal resources that are difficult to obtain from external transactions. 2) The enterprise competence theory defines the enterprise competence as the capability to allocate re- 
sources reasonably and efficiently [15], which is crucial to gain competitive advantage. What's more, most scholars consider that the allocation of resources is a dynamic process. Only when the enterprise can adjust, configure and integrate the internal and external resources according to the change of the market environment can it occupy the favorable position of the market. 3) The knowledge-based theory considers that enterprise is the aggregation of knowledge which is summed up during the long-term practice and operation. Hence, enterprise needs to maintain long-term and continuous learning to expand the field of knowledge and keep competitive advantage.

In the field of supply chain management, the application of the resourcebased theory emphasizes the integration and utilization of the internal and external resources of the enterprise. For startups, capital is one of the scarcest resources for survival and development. Accordingly, supply chain finance, as an effective way for startups to obtain funds, becomes an important direction to study supply chain integration. Meanwhile, interactions can help startups to establish and strengthen social relations and partnership, and get better external resources that they themselves cannot access. Therefore, from the perspective of resource-based theory, this paper discusses the impact of supply chain finance and interaction on achieving higher levels of supply chain integration in startups.

\subsection{Transaction Cost Theory}

The Transaction Cost Theory was proposed by Ronald Coase in 1937 when he put forward the famous Coase Theorem. According to the theory, enterprises acquire external resources in the process of market trading, but at the same time, it also produce transaction costs which may have negative impact on enterprise performance. Hence, rational allocation of resources is the key to reduce transaction costs. Williamson enriched the transaction cost theory on the basis of Coase's research and proposed that asset specificity, transaction uncertainty and transaction frequency were three characteristics in the business process [16]. Besides, he concluded six factors that that could affect the transaction cost of an enterprise: opportunism behavior, bounded rationality, uncertainty, small numbers, information asymmetry and atmosphere. After that, the transaction cost theory has been widely used in social science reseach, including supply chain integration. In fact,the transaction cost theory can explain the formation mechanism of supply chain integration well. For example, Frohlich et al. and Flynn et al. suggest that enterprises that adopt the supply chain integration strategy will invest in specific assets according to their business needs [17] [18]. If an enterprise makes a separate investment in a specific asset, once the business needs to be replaced by the change in the market, that enterprise may have to take an expensive cost. Conversely, if supply chain partners can take a joint investment based on certain agreement, there will be a chance to reduce the risk.

The essence of supply chain is that enterprises can work synergetically to reduce overall transaction cost through the establishment of great partnerships. 
Interaction, as the essential feature of the service supply chain, can help promote the establishment, consolidation and expansion of relationships. Based on the analysis above, this paper will study the relationship between interaction and supply chain integration on the basis of transaction cost theory in startups.

\section{Literature Review and Hypothesis Development}

At present, the definition of service supply chain in the academic circles can be divided into three categories. The first one considers the service supply chain as the service-related links in the supply chain, and the second one describes the service supply chain as the supply chain of the service industry or the service sector. Based on the limitations of the two definitions above, this paper agrees with the third definition that defines the service supply chain as an integrated supply chain which is service oriented [19]. In this supply chain, the supply chain service enterprise occupies a leading position. once the downstream customer makes a service request, the service integrator will respond immediately, and then decompose and assign it to service providers at different service positions to meet requirements step by step. through this process, service providers cooperate with each other and constitute a supply relationship, and the integration and management of various elements in the whole supply chain is undertaken by the service integrator. Hence, in summary, the service supply chain discussed in this study refers to the third type of definition above, which is a supply chain oriented by the integration of resources and service. Besides, scholars have divided the supply chain integration into several dimensions from different angles and structures [2] [5] [6]. Based on previous research, this paper divides the supply chain integration into supplier integration, customer integration and internal integration.

\subsection{Relationship between Interaction and Supply Chain Integration}

Interaction is a typical feature of the service supply chain and it emphasizes the active and conscious mutual influence among the supply chain members. The concept of interaction is different from information exchange and communication. Information exchange is the basis of interaction and communication, while communication means that two parties negotiate and fulfill their commitments in an agreed framework. By contrast, interaction is a process of mutual learning and value co-creation under non-constraint conditions. Hakansson proposed the basic framework of the interactive model, describing interaction using interactive process, interactive subject, environment and atmosphere [20]. In service supply chain, the elements of interaction include all kinds of internal and external resources, such as products, information, funds, service brands and so on. Based on our research objects, this paper discusses the interaction between the startups and the service integrator.

With the rise of service outsourcing, the interaction has become a key link to improve performance of the service supply chain members. Edvardsson and 
Cova believe that the enterprise connections in the service supply chain is no longer a simple supply-demand relationship in upstream and downstream, but an interdependent relationship, which is resulted from the joint action of both parties [21]. Therefore, the interaction in the service supply chain can promote the overall integration of supply chain. Song Hua considers that in current economic context, customer consumption is more and more personalized [19]. The interaction between supply and demand can help deepen the understanding of customer requests, while technological advances make that process much more efficient. More importantly, through supply chain interaction, enterprises can effectively explore partners' resources and capabilities, so as to better cooperate with other supply chain members in terms of strategy, operation and process. At the same time, startups are mostly technology-oriented enterprises who adopt differentiation strategy, and for them interaction can make the capability and effectiveness of resource integration substantially enhanced. Yu et al. propose that interaction is a typical feature of the service supply chain, and it will have an significant impact on cooperation performance [22]. It is considered that it is possible to study in this area [23]. Besides, through empirical research on logistics service supply chain, Gao et al. find that interaction can promote cooperation between supply chain members in upper and lower stream, reduce overall cost of supply chain, and achieve higher level of value co-creation [24]. Hence, we argue that interaction is a capability for supply chain enterprises to gain competitive advantage. Thus, we propose:

$\mathrm{H} 1 \mathrm{a}$ : interaction is positively related to supplier integration

$\mathrm{H} 1 \mathrm{~b}$ : interaction is positively related to customer integration

$\mathrm{H} 1 \mathrm{c}$ : interaction is positively related to internal integration

\subsection{Relationship between Supply Chain Finance and Supply Chain Integration}

Supply chain finance, as an important means to deal with financing difficulties, has effectively solved the fund problem of many small and medium-sized enterprises since the launch of the market. The traditional enterprise financing service is provided by the bank, while the current supply chain finance is now making the capital suppliers more diversified. In order to build a more competitive service supply chain platform and serve customers better, many supply chain service integrators have started to provide supply chain finance service. Unlike the traditional " $1+\mathrm{N}$ " model of the bank and also different from the internet financial model based on big data such as Alibaba and Tencent, the supply chain service integrators make use of their good credit qualifications, sufficient cash flow and other resource advantages to get credit from the bank, and then provide funds for customers who cannot get financing from banks or other channels. Facts have proved that supply chain finance is quite helpful for startups. In entrepreneurial stage, startups do not have strong ability to resist risks and gain stable returns, which leads to the failure of the startups to obtain a higher credit rating, so it is hard for them to get bank loans. By the help of supply chain 
finance, startups can timely get valuable funds through the supply chain service integrator as an intermediary.

Tang et al. research on the financial service in the logistic supply chain by analyzing the small and medium-sized enterprises through the game model, and they draw the conclusion that the development of logistics finance can strengthen the overall integration of supply chain [25]. Peng et al. study and demonstrate that the supply chain finance model of iron and steel industry has a positive impact on the performance of its supply chain integration [26]. Yu et al. put forward the function mechanism of supply chain finance to supply chain integration, and demonstrate that supply chain finance can not only promote the supply chain integration through the flow of funds, but also through information flow and logistics [22]. Thus, based on the theoretical basis above we propose:

H2a: supply chain finance is positively related to supplier integration

$\mathrm{H} 2 \mathrm{~b}$ : supply chain finance is positively related to customer integration

$\mathrm{H} 2 \mathrm{c}$ : supply chain finance is positively related to internal integration

\subsection{Theoretical Model}

Based on the theoretical research basis and hypothesis above, the overall research model is shown in Figure 1. To be mentioned that, due to space constraints, the relationship between supply chain finance and interaction, as well as the indirect effect of interaction on supply chain integration as the intervening variable, will be further studied in the future.

\section{Method}

\subsection{Questionnaire Design and Measure}

The purpose of this paper is to study the impact of interaction and supply chain finance on supply chain integration in the service supply chain. To ensure the reliability and validity of the test scale, most of the questionnaire items used for the measurement of the constructs were adopted from previous studies in the field of supply chain management. The questionnaire is shown in Appendix A.

Items for the interaction variable were selected from Song et al. and Gao et al. which includes seven questions [19] [24]. Items for the supply chain finance variable were selected from Song et al. including seven questions also [19]. Supply chain integration was divided into three parts: supplier integration, internal integration, and customer integration, in which supplier integration included four questions, internal integration included three questions, and customer integration included four questions, all of which were selected from Flynn et al. [2]. All constructs were measured using a five-point Likert scale. All questionnaire items were marked between strongly disagree $(=1)$ and strongly agree $(=5)$ except for information sharing items, which are marked between totally not $(=1)$ and quite extensively (=5). Since the initial questionnaire drawn from English, the items were translated into Chinese by one person, the Chinese version was then 


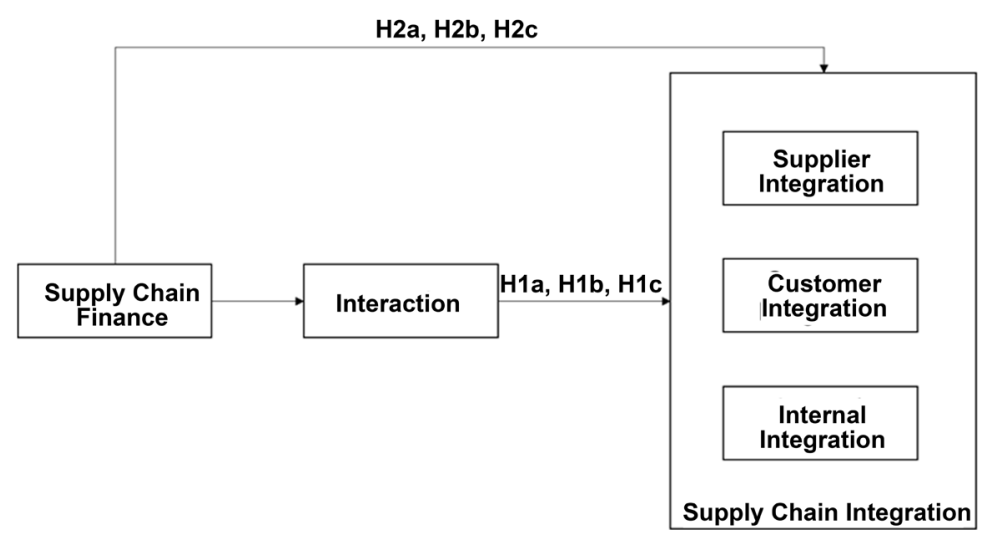

Figure 1. Research model.

translated back into English by another one, and the translated version was checked against the original one, and no discrepancy was found.

\subsection{Sampling and Data Collection}

Different from previous empirical researches on supply chain integration which are based on Western economies, this study focuses on China. Using a large scale empirical study, 65 startups located in Pearl River Delta area, Guangdong Province were investigated. To obtain a representative sample, enterprise yellow pages were used. Besides, relation resources of MBA and EMBA also contribute to our sampling pool. For each randomly selected respondent, we identified a key informant, only those with a title such as president or CEO, vice president, manager, or director that were knowledgeable enough about the firm and its supply chain's internal and external processes were accepted. A profile of the respondents is presented in Table 1 and Table 2, from which we can see that the respondent firms represent a variety of industries, and most of the respondents have been in their position for at least 3 years which indicates that they should be knowledgeable enough about the information requested.

To assess potential late response bias, early and late responses were compared in terms of number of employees, physical assets and annual sales, with a t-test showing no significant differences. Besides, the potential for common method bias was assessed since there was one informant each organization.

\subsection{Reliability and Validity}

The reliability and validity of the data must be tested when the data are used to verify the structural equation. The reliability test of this study uses the Cronbach's a coefficient test and the results are shown in Table 3. It can be seen that the Cronbach's $\alpha$ values of all the variables are greater than 0.75 , which means that the data has good reliability.

Then we use confirmatory factor analysis (CFA) method to test the structural validity and discriminate validity for the data, and the results are shown in Table 4-6. 
Table 1. Profiles of responding companies.

\begin{tabular}{cccccc}
\hline industries & $\begin{array}{c}\text { No. of } \\
\text { firms }\end{array}$ & Capital asserts & $\begin{array}{c}\text { No. of } \\
\text { firms }\end{array}$ & $\begin{array}{c}\text { No. of } \\
\text { workers }\end{array}$ & $\begin{array}{c}\text { No. of } \\
\text { firms }\end{array}$ \\
\hline $\begin{array}{c}\text { Food, beverage and alcohol } \\
\text { textile and apparel }\end{array}$ & 3 & <RMB2M & 13 & $<10$ & 8 \\
Wood and furniture & 2 & RMB2-3M & 17 & $10-50$ & 19 \\
Publishing and printing & 1 & & & & 14 \\
Chemicals and petrochemicals & 4 & RMB3-5M & 15 & $51-100$ & 14 \\
Pharmaceutical and medical & 9 & & & & \\
Mineral and metal & 13 & RMB5-10M & 13 & $101-300$ & 16 \\
mechanical and transportation & 2 & & & & \\
Electronics and electrical & 3 & $>$ RMB10M & 7 & $>300$ & \\
Arts, crafts and jewelry & 25 & & & & \\
Other manufacturing & 3 & & & & \\
Service Industry & 3 & & & & \\
\hline
\end{tabular}

Table 2. Respondent characteristics.

\begin{tabular}{cccc}
\hline position & \% of respondents & Years in current position & $\%$ of respondents \\
\hline Top management & $46.16 \%$ & Less than 0.5 year & $7.7 \%$ \\
Middle management & $29.23 \%$ & 0.5 - 1 years & $16.9 \%$ \\
Other & $24.61 \%$ & $1-3$ years & $32.3 \%$ \\
& & $3-5$ years & $20 \%$ \\
& & More than 5 years & $23.1 \%$ \\
\hline
\end{tabular}

Table 3. Reliability test result.

\begin{tabular}{ccc}
\hline Variable & No. of items & Cronbach's $\alpha$ values \\
\hline Interaction(IA) & 7 & 0.778 \\
Supply Chain Finance (SCF) & 7 & 0.957 \\
Supplier Integration(SI) & 8 & 0.888 \\
Internal Integration(II) & 5 & 0.853 \\
Customer Integration(CI) & 6 & 0.819 \\
\hline
\end{tabular}

From the tables it can be seen that, the model fit indices were $\chi^{2} / \mathrm{df}=1.935$, $\mathrm{CFI}=0.981$, RMSEA $=0.021, \mathrm{RMR}=0.006$, PNFI $=0.580$, PCFI $=0.632$. Thus, the model was acceptable, revealing convergent validity [27]. Furthermore, all the standardized estimates of the measurement items were great than 0.5 , and the t-values were all greater than 2.0, and each item's coefficient is greater than twice its standard error. While Bagozzi and Yi suggested that each factor loading should be greater than 0.50 and all of our 33 items are greater than 0.5 , thus we satisfied the more detailed criteria set by several other studies as indicated above. 
Table 4. Results of CFA.

\begin{tabular}{|c|c|c|c|c|c|c|}
\hline Variable & Question Item & $\begin{array}{c}\text { Factor } \\
\text { Loading }\end{array}$ & C.R. & $\begin{array}{c}\text { Standard } \\
\text { Deviation }\end{array}$ & T-value & P-Value \\
\hline \multirow{7}{*}{ Interaction } & IA 1 & 0.530 & \multirow{7}{*}{0.7696} & -- & -- & -- \\
\hline & IA 2 & 0.506 & & 0.308 & 2.988 & $* * *$ \\
\hline & IA 3 & 0.551 & & 0.280 & 2.758 & $* * *$ \\
\hline & IA 4 & 0.564 & & 0.439 & 3.207 & $* * *$ \\
\hline & IA 5 & 0.568 & & 0.359 & 3.220 & $* * *$ \\
\hline & IA 6 & 0.738 & & 0.443 & 3.691 & $* * *$ \\
\hline & IA7 & 0.607 & & 0.359 & 3.354 & $* * *$ \\
\hline \multirow{7}{*}{$\begin{array}{c}\text { Supply Chain } \\
\text { Finance }\end{array}$} & SCF1 & 0.882 & \multirow{7}{*}{0.9602} & -- & -- & -- \\
\hline & SCF 2 & 0.883 & & 0.110 & 10.364 & $* * *$ \\
\hline & SCF3 & 0.893 & & 0.105 & 10.628 & $* * *$ \\
\hline & SCF4 & 0.855 & & 0.111 & 9.668 & $* * *$ \\
\hline & SCF5 & 0.928 & & 0.094 & 11.654 & $* * *$ \\
\hline & SCF6 & 0.903 & & 0.110 & 10.905 & $* * *$ \\
\hline & SCF7 & 0.815 & & 0.124 & 8.796 & $* * *$ \\
\hline \multirow{8}{*}{$\begin{array}{l}\text { Supplier } \\
\text { Integration }\end{array}$} & SCI1 & 0.750 & \multirow{8}{*}{0.8909} & -- & -- & -- \\
\hline & $\mathrm{SCI} 2$ & 0.785 & & 0.175 & 6.335 & $* * *$ \\
\hline & $\mathrm{SCI} 3$ & 0.870 & & 0.183 & 7.064 & $* * *$ \\
\hline & SCI4 & 0.674 & & 0.177 & 5.363 & $* * *$ \\
\hline & SCI5 & 0.696 & & 0.156 & 5.555 & $* * *$ \\
\hline & SCI6 & 0.635 & & 0.186 & 5.029 & $* * *$ \\
\hline & SCI7 & 0.589 & & 0.135 & 4.636 & $* * *$ \\
\hline & SCI8 & 0.666 & & 0.163 & 5.290 & $* * *$ \\
\hline \multirow{5}{*}{$\begin{array}{c}\text { Internal } \\
\text { Integration }\end{array}$} & II1 & 0.601 & \multirow{5}{*}{0.8606} & -- & -- & - \\
\hline & II2 & 0.668 & & 0.224 & 4.435 & $* * *$ \\
\hline & II3 & 0.912 & & 0.245 & 5.240 & $* * *$ \\
\hline & II4 & 0.732 & & 0.212 & 4.635 & $* * *$ \\
\hline & II5 & 0.783 & & 0.216 & 4.851 & $* * *$ \\
\hline \multirow{6}{*}{$\begin{array}{l}\text { Customer } \\
\text { Integration }\end{array}$} & CI1 & 0.561 & \multirow{6}{*}{0.8207} & -- & -- & -- \\
\hline & $\mathrm{CI} 2$ & 0.693 & & 0.334 & 3.990 & $* * *$ \\
\hline & CI3 & 0.612 & & 0.343 & 3.693 & $* * *$ \\
\hline & $\mathrm{CI} 4$ & 0.507 & & 0.337 & 3.231 & $* * *$ \\
\hline & CI5 & 0.739 & & 0.378 & 4.139 & $* * *$ \\
\hline & CI6 & 0.813 & & 0.349 & 4.327 & $* * *$ \\
\hline
\end{tabular}


Table 5. Overall fitness of CFA.

\begin{tabular}{ccccc}
\hline \multicolumn{2}{c}{ Statistic Value } & Standard & Test Result & $\begin{array}{c}\text { Whether conforms } \\
\text { to the standard }\end{array}$ \\
\hline \multirow{3}{*}{$\begin{array}{c}\text { Absolute fitness } \\
\text { index }\end{array}$} & RMR & $>1$ and $<3$ & 1.935 & yes \\
& RMESA & $<0.05$ & 0.006 & yes \\
& GFI & $>0.08$ & 0.021 & yes \\
Value added & IFI & $>0.9$ & 0.907 & yes \\
fitness & TLI & $>0.9$ & 0.990 & yes \\
& CFI & $>0.9$ & 0.956 & yes \\
Simplified fitness & PNFI & $>0.5$ & 0.981 & yes \\
& PCFI & $>0.5$ & 0.580 & yes \\
\hline
\end{tabular}

Table 6. Discriminant validity test results.

\begin{tabular}{cccccc}
\hline & IA & SCF & SCI & II & CI \\
\hline Interaction(IA) & 0.572 & - & - & - & - \\
$\begin{array}{c}\text { Supply Chain Finance } \\
\text { (SCF) }\end{array}$ & $0.173^{* * *}$ & 0.880 & - & - & - \\
Supplier Integration(SI) & $0.423^{* * *}$ & $0.009^{* *}$ & 0.713 & - & - \\
Internal Integration(II) & $0.403^{* * *}$ & $0.326^{* * *}$ & $0.635^{* *}$ & 0.747 & - \\
Customer Integration(CI) & $0.326^{* * *}$ & $0.004^{* *}$ & $0.563^{* *}$ & $0.587^{* *}$ & 0.663 \\
Mean Value & 22.8154 & 18.3077 & 27.0154 & 17.1692 & 21.8796 \\
Standard Deviation & 3.81155 & 7.11935 & 6.30598 & 4.07189 & 3.72705 \\
\hline
\end{tabular}

Note: ${ }^{* *}$ means $\mathrm{p}<0.001 ;{ }^{* *}$ means $\mathrm{p}<0.05$ (two-tailed).

Therefore, our constructs have convergent validity. Since all modification indices provided by AMOS revealed no parameters that could be released to improve model fit significantly, the discriminant validity was verified. Furthermore, the average variance extracted (AVE) for each construct was greater than the squared correlation [28], as shown in Table 6.

\subsection{Analysis and Results}

This study intended to assess the relationship of the 5 variables: interaction, supply chain finance, supplier integration, internal integration, and customer integration using SPSS 19.0 and the hierarchical regression analysis method and maximum Pseudo-Likehood method is used to estimate the value of model indices and path coefficients.

The hypothesis test results are shown in Table 7 , and it shows that there is a positive correlation between interaction and supplier integration $\left(\beta_{\text {Hla }}=0.423, \mathrm{P}\right.$ $<0.001)$, internal integration $\left(\beta_{H 1 b}=0.403, \mathrm{P}<0.001\right)$ and customer integration $\left(\beta_{H l c}=0.326, \mathrm{P}<0.001\right)$, and supply chain finance also has as significant positive influence on internal integration of startups $\left(\beta_{H 2 b}=0.326, \mathrm{P}<0.001\right)$. However, 
Table 7. Hypothesis test results.

\begin{tabular}{ccccccc}
\hline Dependent Variable & Supplier Integration & \multicolumn{2}{c}{ Internal Integration } & \multicolumn{2}{c}{ Customer Integration } \\
\hline $\begin{array}{l}\text { Independent } \\
\text { Variable }\end{array}$ & $\mathrm{H} 1 \mathrm{a}$ & $\mathrm{H} 2 \mathrm{a}$ & $\mathrm{H} 1 \mathrm{~b}$ & $\mathrm{H} 2 \mathrm{~b}$ & $\mathrm{H} 1 \mathrm{c}$ & $\mathrm{H} 2 \mathrm{~b}$ \\
\hline $\begin{array}{c}\text { Interaction } \\
\begin{array}{c}\text { Supply Chain } \\
\text { Finance }\end{array}\end{array}$ & $0.423^{* * *}$ & & $0.403^{* * *}$ & & $0.326^{* * *}$ & \\
$\mathrm{~F}$ & $13.703^{* * *}$ & $0.005^{* *}$ & $12.196^{* * *}$ & $3.379^{* * *}$ & $7.499^{* * *}$ & $0.001^{* *}$ \\
$\Delta \mathrm{R}^{2}$ & $0.179^{* * *}$ & $0.000^{* *}$ & $0.162^{* * *}$ & $0.051^{* * *}$ & $0.106^{* * *}$ & $0.000^{* *}$ \\
$\mathrm{Max} \mathrm{VIF}$ & 1 & 1 & 1 & 1 & 1 & 1 \\
\hline
\end{tabular}

Note: ${ }^{\star * *}$ means $\mathrm{p}<0.001 ;{ }^{* *}$ means $\mathrm{p}<0.05$ (two-tailed).

there is no significant correlation between supply chain finance, supplier integration $\left(\beta_{H 2 a}=0.009, \mathrm{P}<0.05\right)$ and customer integration $\left(\beta_{H 2 c}=0.004, \mathrm{P}<0.05\right)$. To sum up, the hypothesis $\mathrm{H} 1 \mathrm{a}, \mathrm{H} 1 \mathrm{~b}, \mathrm{H} 1 \mathrm{c}$ and $\mathrm{H} 2 \mathrm{~b}$ are supported, while $\mathrm{H} 2 \mathrm{a}$ and $\mathrm{H} 2 \mathrm{c}$ are rejected. The overall results are shown in Table 8.

\section{Discussion and Management Inspiration}

\subsection{Discussion}

1) Influence of Interaction on Supply Chain Integration.

The key significance between the interaction and supply chain integration has been widely recognized by the theoretical community, but empirical research targeting the special group of start-up companies is very scarce. Through the study of the relationship between interaction and supply chain integration, we found that interaction has positive impacts on supplier integration $(\mathrm{p}<0.001)$, internal integration $(\mathrm{p}<0.001)$ and customer integration $(\mathrm{p}<0.001)$, that is, $\mathrm{H} 1 \mathrm{a}, \mathrm{H} 1 \mathrm{~b}$ and H1c get support. This means that startups can enhance the profundity and level of supply chain integration by enhancing their interaction with service integrators and using service integrators as the medium.

In the service supply chain, the relationship between supply and demand is no longer a simple upstream-downstream relationship, but a mutually dependent commercial-ecology. For startups, from the process of interaction, they not only regard supply chain service integrators as service providers, but also collaborators who help their partners acquire difficult-to-acquire capabilities, knowledge and resources, and build social networks. Correspondingly, supply chain service integrators can learn more about the development pain points of startups, excavate market demand, and innovate service products in this process. Therefore, through interactions, service integrators and startups can share their own experiences, knowledge and capabilities to face the fierce market competition together and realize corresponding value appeals.

2) Supply Chain Finance Impact on Supply Chain Integration Discussion

Although some scholars have suggested that there is an interaction between supply chain finance and supply chain integration, there are few studies to 
Table 8. Results Summary.

\begin{tabular}{clc}
\hline No. & \multicolumn{1}{c}{ Hypothesis Content } & \multicolumn{1}{c}{ Result } \\
\hline H1a & Interaction has a significant positive influence on Supplier Integration & Supported \\
H1b & Interaction has a significant positive influence on Internal Integration & Supported \\
H1c & Interaction has a significant positive influence on Customer Integration & Supported \\
H2a & $\begin{array}{l}\text { Supply Chain Finance has a significant positive influence on Supplier } \\
\text { Integration }\end{array}$ & Rejected \\
H2b & $\begin{array}{l}\text { Supply Chain Finance has a significant positive influence on Internal } \\
\text { Integration }\end{array}$ & Supported \\
H2c & $\begin{array}{l}\text { Supply Chain Finance has a significant positive influence on Customer } \\
\text { Integration }\end{array}$ & Rejected \\
\hline
\end{tabular}

empirically verify the relationship between them, especially for the startups who have the most urgent need for supply chain financial services. This study found that supply chain finance has a positive effect on internal integration $(\mathrm{p}<0.001)$ through research on the relationship between supply chain finance and supply chain integration. This means that in Chinese context, if startups can improve the level of supply chain finance cooperation with their service integrators, that will help startups to realize internal integration.

In reality, there are always some certain "cost depression" in the supply chain. These "costs depression" are often small and medium-sized enterprises with unstable capital chains. These startups have become the bottleneck that restricts the development of supply chain, affecting the stability and financial cost of the supply chain. For startups, they have very good prospects for development, but they are often short-funded because of the adverse payment policies of upstream and downstream companies. In order to help startups solve financing problems, supply chain service integrators use their own credit qualifications as guarantees to provide startups with new financing channels, which not only enriches the means of profit, but also promotes the overall development of the service supply chain.

Besides, integrating supply chain financial services into supply chain management is also an effective way to control supply chain costs. With the help of supply chain finance provided by service integrators, startups can make loans through items such as orders or inventory which cannot be mortgaged by themselves before. In other words, supply chain finance service converts uncontrollable risks into controllable risks and converts uncontrollable costs into controllable costs. To sum up, supply chain finance can provide startups with valuable liquidity funds to better carry out production and business activities, allowing the companies to improve their internal integration and optimizing the overall performance of the supply chain.

\subsection{Management Inspiration}

Based on the empirical analysis results, this study draws the following management implications: 
1) The existence of interaction facilitates the realization of supply chain integration. The global manufacturing industry is facing severe challenges at present and it is imperative to seek industrial upgrading. On the other hand, the demand for industrial upgrading has prompted the transition of traditional supply chains to new service supply chains. In the kind of supply chain, supply chain service enterprises play an important role in resource integration and information transmission. Upstream suppliers and downstream customers can directly interact with supply chain service enterprises to achieve their own demands, which help them to get rid of the complex traditional "1-to-N" mode. For Startups, they must be aware that outsourcing the non-core businesses to supply chain service integrators can enable them to get higher efficiency of resource utilization and better get through the "infancy" period. On other words, the good interaction between startups and supply chain service integrators can help them focus on the construction of core competitiveness and deepen the level of supply chain integration. This kind of interaction can also enable both parties to share their own experiences and capabilities and face problems and dilemmas together. On this basis, start-up companies can achieve their own faster growth, and service integrators can build a more comprehensive service supply chain platform to expand more service projects and realize a "multi-win" situation.

2) Supply chain finance can solve the financial difficulties of startups, thereby promoting the production and operation activities of enterprises, and achieving better internal integration of startups. Most startups are small in scale and have poor ability to resist risks. What's more there is no relevant credit record in the bank, which makes them impossible to obtain loans from the bank. Under such adverse conditions, the supply chain finance service provided by the service supply chain integrators solve the urgent needs of the startups. However, the empirical results of this study shows that supply chain finance does not have a significant effect on the overall integration of supply chain. We consider the reason is that many startups are still using traditional financing ways and lack of understanding of supply chain finance. Therefore, start-up companies should early establish the sense of supply chain finance and use that way to revitalize stock assets and expand financing channels, so as to achieve a higher level of internal integration, and improving the overall performance of supply chain

\section{Conclusion and Limitation}

\subsection{Conclusion}

In this paper, we investigated the impact of interaction, supply chain finance on supply chain integration using the data collected from 65 startups enterprises in the Pearl River Delta Region. We study and explore the relationship with the tool of structural equation modeling and get some practical value of research findings:

Firstly, interaction has a significant positive impact on all the three dimensions of supply chain integration, which means that startups should improve the 
level of communication and cooperation with partners to enhance the degree and levels of integration of the supply chain, and to better cope with the uncertainty of the external environment. Secondly, supply chain finance has a significant positive influence on internal integration, which means that if startups can improve the level of supply chain finance cooperation with their service integrators, that will help startups to realize a better internal effectiveness. Lastly, the results show that the impacts of supply chain finance on supplier integration and customer integration are not significant for startups now under China's market condition, which does not negate the importance of supply chain finance. We speculate the differences might be related to the fact that many startups are still using the traditional ways to financing while they lack full understanding of supply chain finance.

\subsection{Limitation}

The study has several limitations which open up venues and stimulus for further research, which mainly reflected in the following aspects: 1) The indirect value of interaction, this study only considered the direct effect of interaction on supply chain integration for startups, which may have underestimated the indirect effects of supply chain finance through the interaction, thus the indirect value of interaction could be further explored in the future study; 2) Wider geographical and cross-regional market segmentation of research subjects, the research model of this paper is based on the startups enterprises in Pearl River Delta Region, which limits the conclusions to promote in wider region because of the administrative region segmentation in China, and to draw more general conclusions, wider geographical and cross-regional market segmentation could be explored in the future study.

\section{References}

[1] Lang, J. (2017) Research on the Sustainable Development Strategy of Private Enterprises. Modern Economic Information, No. 2, 52-54.

[2] Zhao, X., Huo, B., Flynn, B.B. and Yeung, J. (2008) The Impact of Power and Relationship Commitment on the Integration between Manufacturers and Customers in a Supply Chain. Journal of Operations Management, 26, 368-388. https://doi.org/10.1016/j.jom.2007.08.002

[3] Henk, A. and Bart, V. (2003) Amplification in Service Supply Chain: An Exploratory Case Study. Production and Operations Management, 12, 204-233. https://doi.org/10.1111/j.1937-5956.2003.tb00501.x

[4] Maloni, M.J. and Benton, W.C. (1997) Supply Chain Partnerships: Opportunities for Operations Research. European Journal of Operational Research, 101, 419-429. https://doi.org/10.1016/S0377-2217(97)00118-5

[5] Carlsson, M. (1991) Aspects of the Integration of Technical Functions for Efficient Product Development. R\&D Management, 21, 55-66. https://doi.org/10.1111/j.1467-9310.1991.tb00729.x

[6] Griffin, A. and Hauser, J.R. (1992) Patterns of Communication among Marketing, Engineering, and Manufacturing-A Comparison between Two Product Teams. 
Management Science, 38, 360-373. https://doi.org/10.1287/mnsc.38.3.360

[7] Leonard, B.D. (1992) Core Capabilities and Core Rigidities: A Paradox in Managing New Product Development. Strategic Management Journal, 13, 111-125. https://doi.org/10.1002/smj.4250131009

[8] Ma, W. (2012) An Empirical Study on the Impact of Supply Chain Integration on Firm Performance. South China University of Technology, Guangzhou, 8-17.

[9] Tjosvold, D. (1998) Cooperative and Competitive Interdependence: Collaboration between Departments to Serve Customers. Group and Organization Studies, 13, 274-289. https://doi.org/10.1177/105960118801300303

[10] Ajay, D., Ram, N. and Srinivas, T. (2006) Supplier Integration-Finding an Optimal Configuration. Journal of Operation Management, No. 24, 563-582. https://doi.org/10.1016/j.jom.2005.09.003

[11] Themistocleous, M. and Irani, Z. (2002) Novel Taxonomy for Application Integration. Benchmarking: An International Journal, 9, 154-165.

[12] Wernerfelt, B. (1984) A Resource-Based View of the Firm. Strategic Management Journal, 5, 171-180. https://doi.org/10.1002/smj.4250050207

[13] Barney, J., Wright, M. and Ketchen, D.J. (2001) The Resource-Based View of the Firm: Ten Years after 1991. Journal of Management, 27, 625-641. https://doi.org/10.1177/014920630102700601

[14] Eisenhardt, K.M. and Martin, J.A. (2000) Dynamic Capabilities: What Are They? Strategic Management Journal, 21, 1105-1121. https://doi.org/10.1002/1097-0266(200010/11)21:10/11<1105::AID-SMJ133>3.0.CO; $\underline{2-\mathrm{E}}$

[15] Amit, R. and Schoemaker, P.J.H. (1993) Strategic Asset and Organizational Rent. Strategic Management Journal, 14, 33-46. https://doi.org/10.1002/smj.4250140105

[16] Teece, D. and Pisano, G. (1994) The Dynamic Capabilities of Firms: An Introduction. Industrial \& Corporate Change, 3, 537-556. https://doi.org/10.1093/icc/3.3.537-a

[17] Flynn, B.B., Huo, B. and Zhao, X. (2010) The Impact of Supply Chain Integration on Performance: A Contingency and Configuration Approach. Journal of Operation Management, 28, 58-71. https://doi.org/10.1016/j.jom.2009.06.001

[18] Frohlich, M.T. and Westbrook, R. (2001) Arcs of Integration: An International Study of Supply Chain Strategies. Journal of Operation Management, No. 19, 185-200.

[19] Song, H. (2012) Service Supply Chain. China Renmin University Press Co. Ltd., Beijing, 18-19.

[20] Hakansson, H. (1982) International Marketing and Purchasing of Industrial Goods: An Interaction Approach. Wiley, London, 12-38.

[21] Edvardsson, B., Holmlund, M. and Strandvik, T. (2008) Initiation of Business Relationships in Service-Dominants Settings. Industrial Marketing Management, No. 37, 339-350. https://doi.org/10.1016/j.indmarman.2007.07.009

[22] Yu, H. (2013) A Study on Relationship of Information Technology Capability, Knowledge Management Capability and Supply Chain Performance. Jilin University, Changchun, 9-20.

[23] Chen, J. (2012) Product Supply Capability, Service Integrated Capability and Cooperation Performance: Service Supply Chain Perspective. Economic Management Journal, No. 4, 50-58. 
[24] Gao, Z., Liu, W. and Gao, J. (2014) Value Co-Creation Mechanism of Logistics Service Supply Chain under Service-Dominant Logic. China Business and Market, No. 11, 71-77.

[25] Tang, S. and Qiao, T. (2006) Develop Logistic Finance to Strength Supply Chain Integration. Logistics Technology, No. 2, 99-102.

[26] Peng, R. (2015) Research on Financing Mode of Steel Supply Chain under the Whole Industry Chain Perspective. Finance Economy, No. 14, 127-129.

[27] O’Leary-Kelly, S.W. and Vokurka, R.J. (1998) The Empirical Assessment of Construct Validity. Journal of Operations Management, 16, 387-405. https://doi.org/10.1016/S0272-6963(98)00020-5

[28] Fornell, C. and Larcker, D.F. (1983) Evaluating Structural Equation Models with Unobservable Variables and Measurement Errors. Journal of Marketing Research, No. $12,39-51$. 


\section{Appendix A: The Questionnaire}

The first part of the questionnaire

1) Interactive: Please respond to the actual situation of the interaction between your company and the service integrator (the service integrator refers to a cooperative enterprise providing the supply chain service for your company).

\begin{tabular}{lccccc}
\hline \multicolumn{1}{c}{ Questions } & $\begin{array}{c}\text { Very } \\
\text { disagree }\end{array}$ & Disagree & So-so & Agree & Very agree \\
\hline $\begin{array}{c}\text { The service integrator can understand our } \\
\text { requirements and Strategies }\end{array}$ & 1 & 2 & 3 & 4 & 5 \\
$\begin{array}{c}\text { Service integrator can understand our value } \\
\text { appeal and match our company's culture. }\end{array}$ & 1 & 2 & 3 & 4 & 5 \\
$\begin{array}{c}\text { Service integrator can understand our company's } \\
\text { needs and provide differentiated services. }\end{array}$ & 1 & 2 & 3 & 4 & 5 \\
$\begin{array}{c}\text { Service integrator is willing to share confidential } \\
\text { and important information with our company. }\end{array}$ & 1 & 2 & 3 & 4 & 5 \\
$\begin{array}{c}\text { Service integrator is willing to build integrated } \\
\text { supply chain management relationship. }\end{array}$ & 1 & 2 & 3 & 4 & 5 \\
$\begin{array}{c}\text { Service integrator can provide exact supplier } \\
\text { information in time. }\end{array}$ & 1 & 2 & 3 & 4 & 5 \\
$\quad \begin{array}{l}\text { Service integrator can get our company's } \\
\text { suggestions and share experiences. }\end{array}$ & 1 & 2 & 3 & 4 & 5
\end{tabular}

2) Supply Chain Finance: Please evaluate the following aspects according to your company's participation in the supply chain finance service

Questions Absolutely no Somewhat So-so $\begin{gathered}\text { More } \\ \text { extensive }\end{gathered}$ Widely

Supply chain financial services provide timely financial support for our company.

Supply chain financial services enable our company to get capital and promote production and operation of enterprises.

Supply chain financial services revitalize inventory, accounts receivable and prepaid accounts, improving our company's capital turnover.

Supply chain financial services have effectively integrated business between our company and service integrators.

Our company and service integrator complete the transmission of business information and enterprise information through supply chain financial services.

Supply chain finance simplifies operation procedure and reduces transaction cost.

Our company is willing to acquire funds through supply chain financial services. 
3) Supplier Integration: Please evaluate the following aspects according to the integration of your company and main suppliers.

\begin{tabular}{lccccc}
\hline \multicolumn{1}{c}{ Questions } & $\begin{array}{c}\text { Absolutely } \\
\text { no }\end{array}$ & Somewhat & $\begin{array}{c}\text { So-so } \\
\text { extensive }\end{array}$ & $\begin{array}{c}\text { More } \\
\text { widely }\end{array}$ \\
\hline $\begin{array}{l}\text { We have established strategic partnership } \\
\text { with our main suppliers. }\end{array}$ & 1 & 2 & 3 & 4 & 5 \\
$\begin{array}{l}\text { We set up a quick order processing system } \\
\text { with our main suppliers. }\end{array}$ & 1 & 2 & 3 & 4 & 5 \\
$\begin{array}{l}\text { We share the demand forecast information } \\
\text { with the major suppliers }\end{array}$ & 1 & 2 & 3 & 4 & 5 \\
$\begin{array}{l}\text { We can track the production of main } \\
\text { suppliers in real time. }\end{array}$ & 1 & 2 & 3 & 4 & 5 \\
$\begin{array}{l}\text { The main suppliers have a high degree of } \\
\text { participation in our purchasing and } \\
\text { production process. }\end{array}$ & 1 & 2 & 3 & 4 & 5 \\
$\begin{array}{l}\text { The main suppliers have a high degree of } \\
\text { participation in our company's product } \\
\text { design stage. }\end{array}$ & 1 & 2 & 3 & 4 & 5 \\
$\begin{array}{l}\text { The main suppliers can deliver the goods we } \\
\text { meet on time. }\end{array}$ & 1 & & & & \\
$\begin{array}{l}\text { We help our main suppliers to collaborate } \\
\text { and improve processes to better meet our } \\
\text { needs. }\end{array}$ & 1 & 2 & 3 & 4 & 5 \\
\hline
\end{tabular}

4) Internal Integration: Please evaluate the following aspects according to the integration of various departments within your company.

\begin{tabular}{|c|c|c|c|c|c|}
\hline Questions & $\begin{array}{l}\text { Absolutely } \\
\text { no }\end{array}$ & Somewhat & So-so & $\begin{array}{c}\text { More } \\
\text { extensive }\end{array}$ & widely \\
\hline $\begin{array}{l}\text { We apply cross functional teams } \\
\text { in process optimization. }\end{array}$ & 1 & 2 & 3 & 4 & 5 \\
\hline $\begin{array}{l}\text { We have the ability to carry out } \\
\text { comprehensive inventory management }\end{array}$ & 1 & 2 & 3 & 4 & 5 \\
\hline $\begin{array}{l}\text { Information communication and real-time } \\
\text { connection between different departments } \\
\text { within our company are very smooth. }\end{array}$ & 1 & 2 & 3 & 4 & 5 \\
\hline $\begin{array}{l}\text { Our company has a relatively high degree } \\
\text { of integration among different departments. }\end{array}$ & 1 & 2 & 3 & 4 & 5 \\
\hline $\begin{array}{l}\text { The reaction and resonance of the company } \\
\text { staff to the company culture is high. }\end{array}$ & 1 & 2 & 3 & 4 & 5 \\
\hline
\end{tabular}


5) Customer Integration: Please comment on the following aspects according to the integration of your company and its main customers.

\begin{tabular}{|c|c|c|c|c|c|}
\hline Questions & $\begin{array}{l}\text { Absolutely } \\
\text { no }\end{array}$ & Somewhat & So-so & $\begin{array}{c}\text { More } \\
\text { extensive }\end{array}$ & widely \\
\hline $\begin{array}{l}\text { We have a high degree of agility } \\
\text { to deal with major customer orders }\end{array}$ & 1 & 2 & 3 & 4 & 5 \\
\hline $\begin{array}{l}\text { The main customers share the market } \\
\text { information with us }\end{array}$ & 1 & 2 & 3 & 4 & 5 \\
\hline $\begin{array}{l}\text { We set up a quick order processing system } \\
\text { with our main customers. }\end{array}$ & 1 & 2 & 3 & 4 & 5 \\
\hline $\begin{array}{l}\text { The main customers have a higher degree of } \\
\text { participation in our company's product } \\
\text { design stage. }\end{array}$ & 1 & 2 & 3 & 4 & 5 \\
\hline We follow the main customers to get feedback & 1 & 2 & 3 & 4 & 5 \\
\hline We have closer ties with our main customers & 1 & 2 & 3 & 4 & 5 \\
\hline
\end{tabular}

The second part: Basic Information

1) What industry does your company belong to

\begin{tabular}{cccc}
\hline $\begin{array}{c}\text { A. Food, beverage and } \\
\text { alcohol }\end{array}$ & B. textile and apparel & C. Wood and furniture & $\begin{array}{c}\text { D. Publishing and } \\
\text { printing }\end{array}$ \\
$\begin{array}{c}\text { E. Chemicals and } \\
\text { petrochemicals }\end{array}$ & $\begin{array}{c}\text { F. Pharmaceutical and } \\
\text { medical }\end{array}$ & G. Mineral and metal & $\begin{array}{c}\text { H. mechanical and } \\
\text { transportation }\end{array}$ \\
$\begin{array}{c}\begin{array}{c}\text { I. Electronics and } \\
\text { electrical }\end{array} \\
\text { J. Arts, crafts and } \\
\text { jewelry }\end{array}$ & K. Other manufacturing & L. Service Industry \\
\hline
\end{tabular}

2) Your company's annual income is likely to be (Unit: RMB)?
A) 2 million and below
B) 201 - 300 million
C) 301 - 500 million

D) 501 - 1000 million

E) More than 10 million

\section{3) Total number of employees in your company?}
A) 10 people and below
B) 10 - 50 people
C) 51 - 100 people

$\begin{array}{ll}\text { D) } 101-300 \text { people } & \text { E) } 301 \text { and above }\end{array}$

\section{4) Do you have a position in your company at the moment?}
A) Enterprise owner
B) Middle and senior managers

C) Grass-roots managers

D) Artisan

E) Other

\section{5) The number of years you are working in your company?}
A) Less than half a year
B) 0.5 (containing)- 1 years
C) 1 (containing)-3 years
D) 3 (containing) -5 years
E) 5 years and above

Do we need final research results? ( ), if necessary, Please leave your E-mail:

This questionnaire is over. Thank you for filling in. 